\title{
Determination of the Comfort Level and Self-Care Agency of the Women with Urinary Incontinence
}

\section{Üriner İnkontinansı Olan Kadınların Konfor Düzeyi ve Öz Bakım Gücünün Belirlenmesi}

\author{
Meltem Bozkurt', Evsşen Nazik² \\ 1 Gaziantep Üniversitesi Şahinbey Araştırma ve Uygulama Hastanesi, Gaziantep, Türkiye \\ ${ }^{2}$ Çukurova Üniversitesi Sağlık Bilimleri Fakültesi Hemşirelik Bölümü, Adana, Türkiye
}

\begin{abstract}
Objective: This study was carried out to determine the comfort level and self-care agency of women with urinary incontinence.

Material and Method: This descriptive and relationship seeker research was performed in a, gynecology services of a university hospital between February 2016-April 2018. A total of 124 women with urinary incontinence were included in the study The data of the study were collected by using Personal Information Form, Urinary Incontinence and Urinary Frequency Comfort Scale and Self-Care Agency Scale. Data analysis was done using SPSS windows 24.0 package program.
\end{abstract}

Results: The mean score of Urinary Incontinence and Urinary Frequency Comfort Scale of the women with urinary incontinence was $3.35 \pm 0.59$, and the mean score of SelfCare Agency Scale was $88.09 \pm 14.59$. A statistically significant moderate positive correlation was detected between Urinary Incontinence and Frequency Comfort Scale and Self Care Agency Scale $(r=0.479 p=0.001)$.

Conclusion: It was determined that there is a moderate relationship between the comfort level and self-care agency of women with urinary incontinence in the study.

Keywords: Comfort, self care, urinary incontinence
Öz

Amaç: Bu çalısma, üriner inkontinansı olan kadınların konfor düzeyi ve öz bakım gücünün belirlenmesi amacıyla yapılmıştır.

Gereç ve Yöntem: Tanımlayıcı ve ilişki arayıcı olarak yapılan çalışma, Şubat 2016-Nisan 2018 tarihleri arasında, bir üniversite hastanesinin Kadın Doğum Servisinde yapıımıştır. Araştırmaya 124 üriner inkontinansı olan kadın dahil edilmiştir. Verilerin toplanmasında "Kişisel Bilgi Formu", "Üriner İnkontinans \& Üriner Sıklık Konfor Skalası"ve "Öz bakım Gücü Ölçeği"kullanıımışıır. Verilerin istatistiksel analizleri SPSS Windows version 24.0 paket programında yapılmıştır.

Bulgular:Üriner inkontinansı olan kadınların Üriner İnkontinans \& Sıklık Konfor Skalası toplam puan ortalaması 3,35 $\pm 0,59$ ve Öz

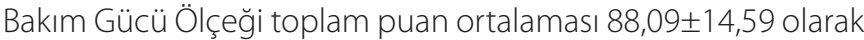
saptanmıştır. Üriner İnkontinans \& Üriner Sıklık Konfor Skalası ile Öz Bakım Gücü Ölçeği arasında, istatistiksel olarak pozitif yönde orta şiddette anlamlı bir ilişki bulunmuştur ( $r=0,479 \mathrm{p}=0,001)$.

Sonuç: Araştırmada üriner inkontinansı olan kadınların konfor düzeyi ile öz bakım gücü arasında orta düzeyde ilişki olduğu belirlenmiştir.

Anahtar Kelimeler: Konfor, öz bakım, üriner inkontinans

Corresponding (illetişim): Evşen Nazik, Çukurova Üniversitesi Sağlık Bilimleri Fakültesi Doğum Ve Kadın Hastalıkları Hemşireliği Anabilim Dalı, Adana, Türkiye 


\section{INTRODUCTION}

Urinary incontinence $(\mathrm{UI})$, which is a medical, hygienic and social problem affecting millions of individuals in the world, is defined as involuntary release of urine. The International Continence Society explained UI as involuntary loss of urine that can be objectively observed and causes social and hygienic problems. $[1,2] \mathrm{UI}$ is a serious health problem that is seen 3-4 times more frequently in women than men, does not threaten life and has economic and emotional effects. The prevalence of $U$ I in women in the literature varies based on age groups, while it is reported between $12 \%$ and 53\%. ${ }^{[3-5]}$ Studies conducted in Turkey have reported this prevalence to vary between $16 \%$ and $69 \% \cdot{ }^{[6-8]} \mathrm{UI}$, which is usually observed in middle-aged and elderly women, is perceived as a normal consequence of ageing, affects the quality of life and sexual functions of women negatively, leads their physical and social lives to be limited and disrupts their comfort. ${ }^{[9-18]}$ Studies have determined that women with UI hide their complaints although their comfort is disrupted, they generally do not visit health institutions, and they try to cope with this problem themselves. ${ }^{[16,18,19]}$

The primarily preferred approach in the treatment of $\mathrm{UI}$ is achievement of lifestyle change. Lifestyle changes consist of various self-care activities including avoiding foods and drinks that irritate the bladder, regulating fluid intake, gaining and maintaining toilet habits, achieving and sustaining an appropriate weight, quitting smoking and managing constipation. ${ }^{[20,21]}$ Self-care involves individuals fulfilling their responsibilities to personally preserve their lives, health and wellbeing. Self-care agency is the capacity of the individual to start and implement health practices to maintain their life, health and wellbeing. For a healthy individual to be able to meet their basic needs and perform their daily life activities, they need to have sufficient self-care agency. ${ }^{[22]}$ Self-care agency is also important in urinary incontinence, whereas a study conducted by Esparza et al. (2018) emphasized that appropriate self-care strategies need to be developed in comping with urinary incontinence. ${ }^{[23]}$

Detection of UI which affects the comfort of women negatively in the early period and performance of the appropriate interventions will provide significant contributions to improvement of women's health. Some of the most important healthcare personnel who will provide this contribution are nurses. Nurses play an active role in the diagnosis and treatment of the problem of incontinence and in increasing the quality of care. ${ }^{[24]}$ It is seen that various studies have been conducted in the literature on women who had UI. ${ }^{[9-18]}$ However, studies examining comfort and self-care agency have not been encountered. This study was conducted to determine the comfort levels and selfcare agency of women with urinary incontinence.

\section{Research questions:}

1. What are the comfort levels of women with urinary incontinence?

2. What are the self-care agency levels of women with urinary incontinence?
3. Is there a relationship between the comfort levels and selfcare agency of women with urinary incontinence?

\section{MATERIAL AND METHOD}

\section{Type of the Study}

This is a descriptive and correlational study conducted to determine the comfort levels and self-care agency of women who have Ul.

\section{Population and Sample}

The study was conducted at the gynecology services of a university hospital between February 2016 and April 2018. The population of this study consisted of the inpatients of this hospital with the diagnosis of UI.

The sample of the study included women who were selected with the non-probability sampling method of random sampling, were hospitalized at the gynecology service of the aforementioned hospital with the diagnosis of $\mathrm{UI}$, met the inclusion criteria of the study and agreed to participate in the study.

\section{The inclusion criteria were as follows:}

- Being at or over the age of 18 ,

- Not having had any surgical operation due to UI,

- Not having difficulty in communication or a diagnosed psychiatric disease,

- Being able to understand and speak Turkish.

Power analysis was conducted in the G*Power software to calculate the sample size. Based on the study by Zengin (2008), with a $95 \%$ power and a $5 \%$ error rate, it was determined that at least 105 women needed to be included. ${ }^{[2]}$ By considering the possibility of the women to want to leave the study and fill out the questionnaire forms incompletely, the study was conducted with 124 women.

\section{Data Collection}

The data were collected by the researcher with the face-toface interview method between February 2016 and April 2018 at the gynecology services of the specified hospital, and each interview lasted for about 20.

\section{Data Collection Instruments}

The data were collected using a "Personal Information Form" 1 on the descriptive characteristics of the participants, the "Urinary Incontinence and Urinary Frequency Comfort Scale" to assess comfort and the "Self-Care Agency Scale" to assess self-care.

\section{Personal Information Form}

It consisted of 25 questions on the sociodemographic (age, education status, employment status, health insurance status, income level, marital status, duration of marriage), obstetric (number of pregnancies, age of pregnancy, form of delivery, etc.) and UI diagnosis-related (type of incontinence, duration of complaints, precautions taken, etc.) characteristics, their cigarette/alcohol use status and chronic disease status. 


\section{Urinary Incontinence and Urinary Frequency Comfort Scale}

It was developed by Dowd et al. (2000) to assess the comfort of the individual experiencing problems of urinary incontinence and frequent urination by utilizing the General Comfort Scale of Kolcaba. ${ }^{[25]}$ Its validity and reliability in Turkey were tested by Zengin (2008). ${ }^{[12]}$ The scale is a 28-item 6-point Likerttype scale with options ranging from "absolutely disagree" to "absolutely" agree. 16 of the expressions in the items are positive $(1,2,4,9,11,12,13,15,16,17,23,24,25,26,27,28)$, 12 are negative $(3,5,6,7,8,10,14,18,19,20,21,22)$, and the negative items are inversely scored in calculation of the total score. The lowest and highest possible total scores in the scale are 28 and 168 . However, while assessing the scale, by dividing the total score by the number of items, an average score is obtained, and the result is evaluated in the range of 1-6. Low scores indicate poor comfort, whereas high scores indicate good comfort. The Cronbach's alpha value of the scale in its reliability study was determined as 0.77 . In this study, the Cronbach's alpha value was calculated as 0.84 .

\section{Self-Care Agency Scale}

The Self-Care Agency Scale developed by Kearney and Fleisher in 1979 consists of 43 items. $^{[26]}$ Nahcivan adapted the scale into the Turkish society by conducting a validity and reliability study on the scale with healthy young people in 1993. ${ }^{[27]}$ The scale adapted to the Turkish society is a 35item, 5-point Likert-type scale. Each item has the options of "does not define me at all", "somehow does not define me", "undecided", "somehow defines me" and "defines me a lot." In the scale translated into Turkish, items 3, 6, 9, 13, 19, 22, 26 and 31 are negatively and the other items are positively scored. The positive expressions in the scale are scored as $0,1,2,3$, 4 points, while the negative ones are scored as 4, 3, 2, 1, 0 points, respectively. The minimum and maximum total scores in the scale are 35 and 140. High scores indicate high levels of self-care agency. The Cronbach's alpha value of the scale was reported as 0.89 . In this study, the Cronbach's alpha value of it was found as 0.81 .

\section{Data Analysis}

The SPSS Windows version 24.0 package program was used for the statistical analyses. As the descriptive statistics, mean \pm standard deviation for the numerical variables and frequency and \% for the categorical variables are presented. The relationship between the numerical variables was determined by Spearman's correlation analysis. Cronbach's alpha coefficients were calculated to test validity and reliability. $p<0.05$ was accepted as statistically significant.

\section{Ethical Aspects}

Before starting the study, the protocol was submitted to the Non-Interventional Clinical Studies Ethics Board of the School of Medicine at Çukurova University, and approval was obtained (06-11-2015/45). Additionally, written permission was also obtained from the institution where the study was conducted. To protect the rights of the women included in the study, information was provided to the participants about the purpose of the study before data collection, and those who volunteered were included. The "autonomy" principle was followed by stating that the women could leave the study whenever they wanted, while the "confidentiality and protection of privacy" principle was followed by assuring them that their individual information would be protected. By stating that the identity of the obtained information and the respondent would be kept hidden, the principle of "anonymity and security" was complied with.

\section{RESULTS}

The following findings were obtained in the study that was conducted to determine the comfort levels and self-care agency of women with urinary incontinence.

\section{Sample Characteristics}

The mean age of the participants was $48.03 \pm 7.78$ (range: 18-62), $84.7 \%$ were at or over the age of $40,38.7 \%$ were primary school graduates, and $83.9 \%$ were not working. Among the women, $88.7 \%$ had health insurance, $72.6 \%$ had moderate income levels, $78.2 \%$ were married, and the duration of marriage of $62.5 \%$ was 21 years or longer (Table 1 ).

\begin{tabular}{|c|c|c|}
\hline Sociodemographic Characteristics & Frequency & Percentage \\
\hline \multicolumn{3}{|l|}{ Age } \\
\hline 39 years or younger & 19 & 15.3 \\
\hline 40 years or older & 105 & 84.7 \\
\hline \multicolumn{3}{|l|}{ Education Level } \\
\hline Illiterate & 12 & 9.7 \\
\hline Literate & 34 & 27.4 \\
\hline Primary School & 48 & 38.7 \\
\hline Secondary School & 13 & 10.5 \\
\hline High School & 13 & 10.5 \\
\hline University or higher & 4 & 3.2 \\
\hline \multicolumn{3}{|l|}{ Employment Status } \\
\hline Working & 20 & 16.1 \\
\hline Not working & 104 & 83.9 \\
\hline \multicolumn{3}{|l|}{ Has Health Insurance } \\
\hline Yes & 110 & 88.7 \\
\hline No & 14 & 11.3 \\
\hline \multicolumn{3}{|l|}{ Income Level } \\
\hline Good & 9 & 7.3 \\
\hline Moderate & 90 & 72.6 \\
\hline Bad & 25 & 20.1 \\
\hline \multicolumn{3}{|l|}{ Marital Status } \\
\hline Married & 97 & 78.2 \\
\hline Single & 27 & 21.8 \\
\hline \multicolumn{3}{|l|}{ Duration of Marriage } \\
\hline 1-5 year(s) & 5 & 5.2 \\
\hline $6-10$ years & 7 & 7.3 \\
\hline $11-15$ years & 7 & 7.3 \\
\hline $16-20$ years & 18 & 17.7 \\
\hline 21 years or longer & 60 & 62.5 \\
\hline
\end{tabular}


Considering the obstetric and gynecological characteristics of the participants, it was determined that the total number of pregnancies of $65.3 \%$ of the women was 4 or higher, while the total number of births of $44.9 \%$ was 4 or higher. $55.1 \%$ had their first birth at the ages of $19-24.66 .1 \%$ of the women had normal delivery, and $94.1 \%$ did not have multiple gestation. $67.7 \%$ had not had any gynecological operation before, and $57.3 \%$ had not entered menopause. Among those who had entered menopause, it was found that $37.7 \%$ entered menopause in the age range of 46-50.

Among the included women, $36.3 \%$ were overweight, $74.2 \%$ did not smoke, $54.5 \%$ of the smokers smoked 20 cigarettes a day, $92.7 \%$ never used alcohol, $51.6 \%$ did not have a chronic disease, and $41.7 \%$ of those with chronic diseases had hypertension.

Considering the Ul-related findings of the participants, it was found that $36.3 \%$ of the women experienced stress urinary incontinence, $71.8 \%$ had complaints of urinary incontinence for 1-5 year(s), 46\% experienced incontinence more than once a day. It was determined that $85.5 \%$ of the women took precautions about their problem of urinary incontinence. $52.8 \%$ said they went to the toilet frequently as a precaution, while $49.1 \%$ stated that they reduced their fluid intake (Table 2 ).

$\begin{array}{lcc}\text { Table 2. Distribution of the Ul-Related Characteristics of the Women with } \\ \text { Urinary Incontinence (N=124) } & \mathbf{n} & \% \\ \text { Incontinence-related characteristics } & & \\ \text { Type of Incontinence } & 38 & 30.6 \\ \text { Urge Incontinence } & 45 & 36.3 \\ \text { Stress Incontinence } & 41 & 33.1 \\ \quad \text { Mixed type } & & \\ \text { Duration of Incontinence } & 89 & 71.8 \\ \text { 1-5 year(s) } & 25 & 20.1 \\ \text { 6-10 years } & 10 & 8.1 \\ \text { 11 years or longer } & & \\ \text { Frequency of Incontinence } & 30 & 24.2 \\ \text { Once a day } & 57 & 46.0 \\ \text { More than once a day } & 13 & 10.5 \\ \text { Once a week } & 24 & 19.4 \\ \text { More than once a week } & & \\ \text { Takes Precaution } & 106 & 85.5 \\ \text { Yes } & 18 & 14.5 \\ \text { No } & & \\ \text { Precaution Taken* } & 28 & 26.4 \\ \text { Using protective pads } & 56 & 52.8 \\ \text { Going to the toilet frequently } & 52 & 49.1 \\ \text { Intaking less fluids } & 30 & 28.3 \\ \text { Sitting near the toilet } & & \\ \text { *Multiple choices were allowed. } & \end{array}$

\section{Relationship between Comfort and Self-Care Agency}

Table 2 shows the total mean scores of the Urinary Incontinence and Urinary Frequency Comfort Scale and the Self-Care Agency Scale. The mean total scores of the women with UI from these scales were $3.35 \pm 0.59$ and $88.09 \pm 14.59$, respectively (Table 3).

\begin{tabular}{|c|c|c|c|}
\hline Scales & Med & Min-Max & $\mathrm{X} \pm \mathrm{SD}$ \\
\hline $\begin{array}{l}\text { Urinary Incontinence and Urinary } \\
\text { Frequency Comfort Scale }\end{array}$ & 3 & $1-6$ & $3.35 \pm 0.59$ \\
\hline Self-Care Agency Scale & 89 & $54-116$ & $88.09 \pm 14.59$ \\
\hline
\end{tabular}

The Spearman's rank correlation value between the mean scores of the Urinary Incontinence and Urinary Frequency Comfort Scale and the Self-Care Agency Scale was found as $r=0.479(p=0.001)$, which indicated a moderate, positive and significant relationship between the two scales (Table 4).

Table 4. Relationship between the Urinary Incontinence and Urinary Frequency Comfort Scale and the Self-Care Agency Scale

\begin{tabular}{lccc}
\multirow{2}{*}{ Scales } & \multicolumn{3}{c}{$\begin{array}{c}\text { Urinary Incontinence and Urinary } \\
\text { Frequency Comfort Scale }\end{array}$} \\
\cline { 2 - 5 } & $\mathbf{n}$ & $\mathbf{r}$ & $\mathbf{P}$ \\
\hline Self-Care Agency Scale & 124 & $0.479^{*}$ & $0.001^{* *}$ \\
\hline
\end{tabular}

\section{DISCUSSION}

$\mathrm{UI}$ is one of the significant gynecological disorders that disrupt the health status of women and affect their quality of life. It was determined that, among the women who participated in the study, 36.3\% experienced stress urinary incontinence (SUI), 33.1\% experienced mixed urinary incontinence (MUI), and $30.6 \%$ experienced urge incontinence (UI). It was found that SUI was seen more frequently in the participants. Öztürk et al. (2012) found urge incontinence to be the most frequent type of incontinence, Terzi et al. (2013) observed MUI most frequently, followed by SUI in women, and in the study by Dinç and Özer (2019), the most frequently seen incontinence type was SUI (54.2\%). ${ }^{[28-30]}$ While the most frequently observed type of incontinence was MUI in some studies, it was SUI in some others. It is thought that this difference was caused by that these studies were conducted on different age groups.

In the study, $85.5 \%$ of the participants stated that they took precautions about UI. These precautions were determined as going to the toilet frequently, using protective pads, intaking less fluids and sitting near the toilet. According to the study by Demir and Kızılkaya (2015), the precautions of women related to $\mathrm{UI}$ included looking for a toilet that could be reached immediately at unknown places by $69.5 \%$, frequent underwear change by $60.6 \%$, using pads, fabrics, cotton, etc. by $57.2 \%$, keeping the feet warm by $46.2 \%$, going to the toilet frequently by $36 \%$, not lifting heavy weights by $24 \%$, taking frequent baths by $24 \%$, and visiting only places that have toilets by $23.3 \%{ }^{[13]}$ Esparza et al. (2018) determined that women and men with UI performed self-care activities like taking a bath, wearing comfortable clothes, finding the location of toilets outside the home, controlling fluid intake and using incontinence pads. The findings of this study were similar to those in the literature. ${ }^{[23]}$ In this study, the mean total score of the women in the Urinary Incontinence and Urinary Frequency Comfort Scale was found as $3.35 \pm 0.59$. This scale has a minimum score of 1 and a maximum score of 6 . 
Low scores indicate poor comfort, while high scores indicate good comfort. In this study, the comfort levels of the women who had UI were found to be moderate. Likewise, Rassin et al. also found the comfort levels of women with $\mathrm{Ul}$ as moderate $(2.95 \pm 0.04){ }^{[3]}$ Studies have reported that UI affects the comfort, and therefore the quality of life, of women negatively. $[2,15-17]$ Comfort is an important component of quality of life, and when the lives of individuals are more comfortable, their quality of life increases. It is considered that the physical, psychological and social effects of $\mathrm{Ul}$ influence the comfort of the woman negatively.

In this study, the mean total score of the participants in the SelfCare Agency Scale was determined as $88.09 \pm 14.59$. The lowest and highest possible scores in this scale are 35 and 140 . High total scores in the scale indicate that the individual is independent and capable in performing their self-care. In this study, the self-care agency levels of the women with UI were found to be moderate. An individual with sufficient self-care agency can meet their self-care needs, take the responsibility of their own health and perform life activities without dependence on others. Although urinary incontinence is not a life-threatening problem, it negatively affects quality of life due to constantly being wet and having irritation and leads to economic, social and emotional problems. ${ }^{[32,33]}$ Better self-care of women may help them seek treatment for urinary incontinence and cope more effectively with the problems they experience.

In this study, a moderate, positive and significant relationship was found between the mean scores of the Urinary Incontinence and Urinary Frequency Comfort Scale and the Self-Care Agency Scale. This result showed that, as the self-care agency of the women increased, their comfort levels also increased. Selfcare involves personal fulfillment of one's own responsibilities to protect own life, health and wellbeing. Self-care agency is defined as the capacity of the individual to start and implement health activities to maintain their life, health and wellbeing. In $\mathrm{UI}$, avoiding foods and drinks that irritate the bladder, regulating fluid intake, gaining toilet habits, having an ideal body weight, quitting smoking and preventing constipation are among selfcare activities. If women who have UI can perform these selfcare activities, their UI-related problems may decrease, and their comfort may increase. No studies investigating both the self-care and comfort of women with UI could be encountered in the literature. However, there are studies which determined that self-care training given to those with $\mathrm{UI}$ increased their quality of life. ${ }^{[34,35]}$ Therefore, it is believed that it is needed to assess the self-care agency levels of women to be able to increase their comfort, and therefore, their quality of life.

\section{CONCLUSION}

In this study that was carried out to determine comfort levels and self-care agency in women with UI, it was determined that the participants had moderate levels of comfort and self-care agency, and as their self-care agency increased, their comfort levels also increased. In line with these results, nurses may be recommended to assess the comfort levels and self-care agency of women who have UI, provide training for women regarding information on and prevention of incontinence and offer counselling towards increasing women's comfort levels and self-care agency.

\section{ETHICAL STATEMENTS}

Ethics Board Approval: Before starting the study, the protocol was submitted to the Non-Interventional Clinical Studies Ethics Board of the School of Medicine at Çukurova University, and approval was obtained (06-11-2015/45).

Informed Consent: Written consent was obtained from the patients who participated in this study.

Reviewer Assessment Process: External double-blind reviewer assessment.

Conflict of Interest Status: The authors state that they do not have any conflict of interest regarding this study.

Financial Support: The authors declare that they have not received any financial support for this study.

Author Contribution: All authors participated in the design, implementation and analysis of the study and approve the final version of the manuscript.

\section{REFERENCES}

1. Abrams P, Artibani W, Cardozo L, Dmochowski R, van Kerrebroeck $\mathrm{P}_{\text {, }}$ Sand P. Reviewing the ICS 2002 terminology report:the ongoing debate. Neurourol Urodyn 2009;28 (4):287.

2. Zengin N. İdrar Kaçıran Kadınlarda Hemşirelik Eğitimi ve Davranışsal Tedavinin Konfor, Pelvik Taban Kas Egzersizi Uygulaması, Öz-etkililik Algısı ve Yaşam Kalitesine Etkisi. Doktora tezi, Marmara Üniversitesi, İstanbul, 2008.

3. Syan R, Brucker BM. Guideline of guidelines:urinary incontinence. BJU International, 2015;117:20-33.

4. Cerruto M, D'Elia C, Aloisi A, Fabrello M, Artibani W. Prevalence, incidence and obstetric factors'impact on female urinary incontinence in Europe:a systematic review. Urologia Internationalis, 2012;3:1-9.

5. Townsend MK, Curhan GC, Resnick NM, Grodstein F. The incidence of urinary incontinence across Asian, black, and white women in the United States. American Journal of Obstetrics and Gynecology, 2010;378:1-7.

6. Zengin N. Kadınlarda idrar kaçırma prevelansı ve risk faktörleri. Fırat Sağlık Hizmetleri Dergisi, 2010;13:45-60.

7. Başak T, Uzun S, Arslan F. incontinence features, risk factors and quality of life in Turkish women presenting at the hospital for urinary incontinence. J Wound Ostomy Continence Nurs., 2012;39 (1):84-89.

8. İrer B, Șen V, Demir Ö, Bozkurt O, Esen A. Üriner inkontinans alt tiplerinin yaşam kalitesi üzerine etkileri:doktora başvurmada üriner inkontinans alt tipinin önemi var mı? Ortadoğu Tıp Dergisi, 2018;10 (1):8-12.

9. Yılmaz E, Muslu A, Özcan E. Üriner İnkontinanslı Kadınlarda Yaşam Kalitesi. Erciyes Üniversitesi Sağlık Bilimleri Fakültesi Dergisi, 2014;2 (2):1-14.

10. Işıklı B, Yenilmez A, Kalyoncu C. Eskişehir Alpu İlçesi 18 Yaş Üstü Kadınlarda Üriner İnkontinans, Risk Faktörleri Ve Yaşam Kalitesine Etkisi. Nobel Medicus, 2011;7 (2):34-39.

11. Demirci N, Aba YA, Süzer F, Karadağ F, Ataman H. 18 Yaş Üstü Kadınlarda Üriner İnkontinans ve Yaşam Kalitesine Etkileri. Fırat Sağlık Hizmetleri Dergisi, 2012;7 (19):23-37.

12. Ünsal A, Tözün M, Arslantaş D. Eskişehir ili Beylikova ilçe merkezinde 20 yaş ve üzeri kadınlar arasında üriner inkontinans, ilişkili faktörler ve depresyon. TAF Prev Med Bull, 2013;12:231-242. 
13. Demir S, Kızılkaya Beji N. Üriner İnkontinanslı Kadınlarda Yaşam Kalitesi ve Sağlık Arama Davranışları. F.N. Hem. Derg, 2015;23 (1):23-31.

14.Güngör Uğurlucan F, Comba C, Emegil ş, Yalçın Ö. Türkiye'de Üriner İnkontinans Ille Illgili Düşünce Ve Tutumlar. İstanbul Tıp Fakültesi Dergisi, 2016;79 (4):141-146.

15. Fultz $\mathrm{NH}$, Herzog AR. Self-report social and emotional impact of urinary incontinence. J Am Geriatr Soc, 2001;49:892-899. Hagglund D, Ahlström $\mathrm{G}$. The meaning of women's experience of living with long-term urinary incontinence is powerlessness. Journal of Clinical Nursing, 2007;10 (16):1946-1954.

16. Zaccardi JE, Wilson L, Mokrzycki ML. The effect of pelvic floor re-education on comfort in women having surgery for stress urinary incontinence. Urol Nurs., 2010;30(2):137-148.

17. Çiloğlu D, Zaybak A. Üriner inkontinanslı bireylerde baş etme davranışları ve yaşam kalitesi. Türkiye Klinikleri Hemşirelik Bilimleri 2020;12(1):64-71.

18. Ertem G. Üriner inkontinanslı hastaların hastalığıyla başa çıkma yollarının incelenmesi. Uluslararası İnsan Bilimleri Dergisi, 2009;6 (1):177-187.

19. Wood LN, Anger JT. Urinary incontinence in women. BMJ, 2014:26-30.

20. Burkhard FC, Bosch JLHR, Cruz F, Lemack GE, Nambiar AK, Thiruchelvam N, Tubaro A. Eau Guidelınes On Urınary Incontınence. Eur Assoc Urol 2017:153-154.

21. Velioğlu P. Hemşirelikte Kavram ve Kuramlar. İstanbul:Alaş Ofset, 1999.

22. Esparza AO, Tomas MAC, Pina-Roche F. Experiences of women and men living with urinary incontinence:A phenomenological study. Appl Nurs Res., 2018;40:68-75.

23. Başgöl Ş, Kızılkaya Beji N. Kontinans Hemşirelerinin Gelişen Rollerinin Uluslararası Düzeyde İrdelenmesi. F.N. Hem. Derg, 2015;23(3):224-230.

24. Dowd T, Kolcaba KY, Steiner R. Using cognitive strategies to enhance bladder control and comfort. Holist Nurs Pract, 2000;14 (2):91-103.

25. Kearney BY, Fleischer BJ. Development of an instrument to measure exercise of self-care agency. Res Nurs Healt, 1979;22:25-34.

26. Nahcıvan NÖ. Sağlıklı gençlerde Öz-bakım gücü ve aile ortamının Etkisi. Doktora Tezi, İstanbul Üniversitesi Sağlık Bilimleri Enstitüsü Halk Sağlığı Anabilim Dalı, İstanbul, 1993.

27. Öztürk GZ, Toprak D, Basa E. 35 yaş üzeri kadınlarda üriner inkontinans sıklığı ve etkileyen faktörlerin değerlendirilmesi. SETB. 2012;46(4): 170176.

28. Terzi , Terzi R, Kale A. 18 yaş üstü kadınlarda üriner inkontinans sıklığı ve etkileyen faktörler. Ege Tıp Derg 2013;52(1):15-19 15.

29. Dinç A, Özer NE. Premenopoz ve Menopozal Dönemdeki Kadınlarda Üriner İnkontinans Görülme Sıklığı ve Risk Faktörlerinin Incelenmesi. GÜSBD 2019;8(2):1-9.

30.31. Rassin M, Dubches L, Libshitz A, Adar E. Levels of comfort and ease among patients suffering from urinary incontinence. Int J Urol Nurs 2007;1(2): 64-70.

31. Aoki Y, Brown HW, Brubaker L, Cornu JN, Daly JO, Cartwright R. Urinary incontinence in women. Nat Rev Dis Primers. 2017;3(6):17042.

32. St John W, Griffiths S, Wallis M, McKenzie S. Women's management of urinary incontinence in daily living. J Wound Ostomy Continence Nurs. 2013;40(5):524-32.

33. Azizi M, Azadi A, Otaghi M. The effect of a self-care programme on urinary incontinence and self-esteem in elderly men dwelling in nursing homes in Iran. The Aging Male, 2019;15:1-7.

34. Kolbadinezhad N, Hasanpur M , Mahmudi M , Ayyasi M. The effect of education based on family-centered empowerment model on the selfcare behaviors of the women suffering from stress urinary incontinence. Iran J Rehabil Res Nurs 2020; 6(2):-64-71. 